\begin{tabular}{|c|c|c|}
\hline$W_{\text {INESEG }}$ & $\begin{array}{l}\text { INTERNATIONAL } \\
\text { ENGINEERING, } \\
\text { SCIENCE AND } \\
\text { EDUCATION } \\
\text { GROUP }\end{array}$ & $\begin{array}{l}\text { Middle East Journal of Science } \\
\text { (2017) 3(2): } 140 \text { - } 146 \\
\text { Published online December 25, } 2017 \quad \text { (http://dergipark.gov.tr/mejs) } \\
\text { doi: } 10.23884 / \text { mejs.2017.3.2.08 } \\
\text { ISSN: } 2536-5312 \\
\text { Received: October 03, } 2017 \quad \text { Accepted: December 13, } 2017\end{array}$ \\
\hline
\end{tabular}

\title{
A RESEARCH ON FRUIT PRODUCTION POTANTIAL OF MARDIN PROVINCE
}

\section{Mikdat ŞIMSSEK ${ }^{1}$ Ersin GÜLSOY*2}

${ }^{* 1}$ Dicle University, Faculty of Agriculture, Department of Horticulture, Diyarbakir, Turkey

${ }^{2}$ Igdir University, Faculty of Agriculture, Department of Horticulture, Igdir, Turkey

* Corresponding author; ersin.gulsoy@igdir.edu.tr

\begin{abstract}
Mardin province is one of the oldest and rarest settlements with a number of religious cultural heritage where agricultural production emerged first. According to 2016 year statistics, it has a share of $0.11 \%$ in Turkey's total fruit production which indicates that it is not a considerable fruit producer. Whereas, in this province, a number of fruit species can commercially be grown and cherry, pomegranate, pistachio, almond, olive and figs production is more prominent. Mardin has a terrestrial climate with considerably hot and dry summers, and cold winters. According to 2016 statistics total fruit production was realized to be 16.229 tons in Mardin. Considering the 2016 year total fruit production of Mardin districts, Kiziltepe, Omerli and Artuklu rank first, second and third with 3.424, 2.903 and 2.467 tons of fruit productions respectively as Mazidagi is the last with a production of 207 tons. Again, regarding the fruit production by species, 2.965 tons of pomegranate, 2.946 tons of cherry, 1.921 tons of pistachio, 1.888 tons of almond and 1.741 tons of olive were produced in Mardin in 2016. In this study, through presenting the existing status of the fruit production potential of the Mardin province, it was aimed to increase the awareness and set light to decision makers in future plans for making use of the existing fruit potential of Turkey.
\end{abstract}

Key Words: Mardin, Fruit production potantial, Development opportunities

\section{Introduction}

In general, fruit production is of great importance because of human nutrition, raw material supply for industry and foreign trade [9].

Turkey has a quite large potential regarding both fruit species and production in the world [6]. and has favourable ecological conditions for growing many fruit species [9]. It is a gene centre for many fruit species such as apricots, figs, hazelnuts, almonds, walnuts, pomegranates, pistachio, apple and cherry. According to archaeological research, It has been known that many fruit species were grown in Anatolia a few thousand years ago $[8,5,7]$. In this context, Mardin is one of the oldest and rarest 
settlements with a number of religious cultural heritage where agricultural production emerged first. According to 2016 year statistics, it has a share of $0.11 \%$ in Turkey's total fruit production which indicates that it is not a considerable fruit producer [1]. Whereas, a number of fruit species can commercially be grown and cherry, pomegranate, pistachio, almond, olive and figs production is more prominent [1]. Mardin has a terrestrial climate with considerably hot and dry summers, wet and cold winters and $730 \mathrm{~mm}$ of annual rainfall [3].

In this study, through presenting the existing status of fruit production potantial of Mardin province of Southeast Anatolia region in Turkey, it was aimed to increase the awareness and set light to decision makers.

\section{Mardin Province's Fruit Productıon Potantial}

Mardin province in Turkey map and the districts's map of Mardin were given Figure 1 and Figure 2, respectively. Turkey has 237.625.723 decares of area of agricultural land and 33.292.166 decares of the area for fruits and the beverage-spice crops [1]. Pear, quince, almond, walnut, pistachio, apple, plum, mulberry, fig, apricot, cherry, peach, nectarine, pomegranate, Persimmon, Loquat, wild apricot, cherry and olive are grown in Mardin province (Table 1). According to the year of 2016, Mardin province has 16.229 tons of fruit potantial production, 1.157 .459 of number of fruitful trees, 563.966 of number of unfruitful trees and 1.721 .425 of total number of trees (Table 1). Pear, Quince, almond, walnut, apple, plum, mulberry, pistachio, pomegranate, persimmon, figs, apricot, peach, nectarine, loquat, Jerusalem, Sour cherry, olive and cherry are grown in Mardin province. Pomegranate, cherry and olive production in Mardim province rank first, second and third with 2.965, 2.946 and 1.711 tons, respectively. Persimmon and Loquat's fruit production are the last place with 6 tons. In this context, Mardin Province is suitable for the cultivation of many fruit species and varieties.

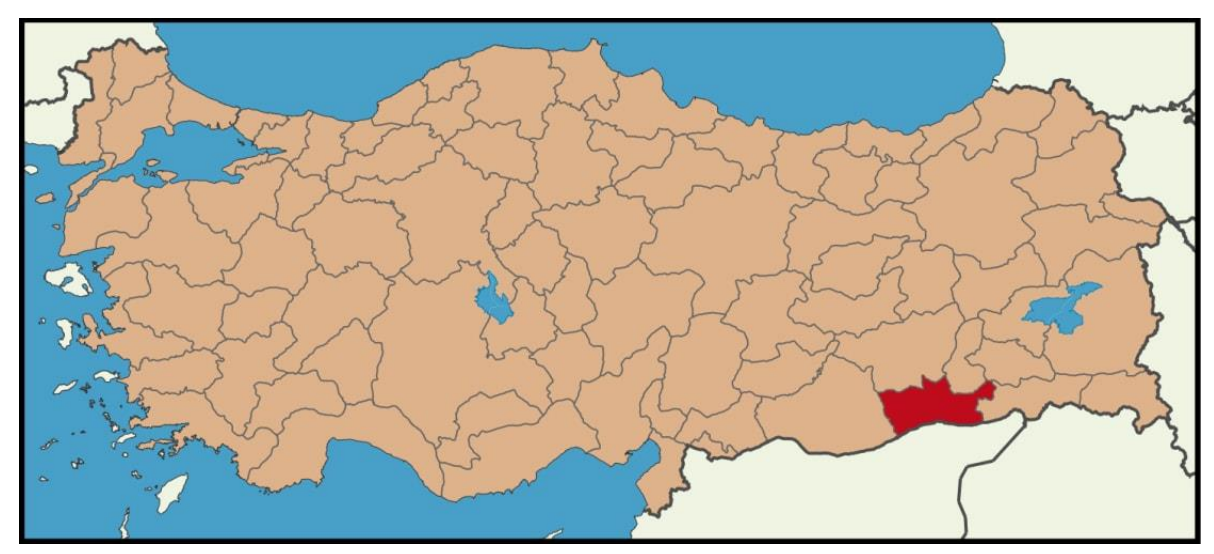

Figure 1. Mardin province in Turkey map [4]. 


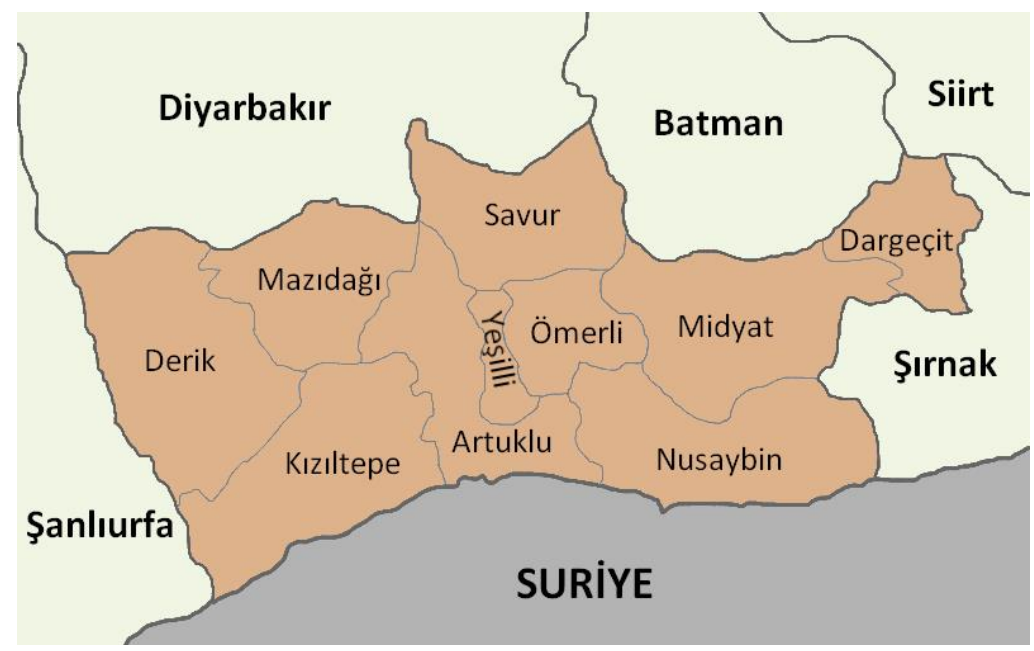

Figure 2. The Districts's Map of Mardin province [2].

Table 1. Mardin province's fruit production according to 2016.

\begin{tabular}{|c|c|c|c|c|c|c|}
\hline $\begin{array}{c}\text { Name of } \\
\text { Fruit } \\
\text { Species }\end{array}$ & $\begin{array}{c}\text { Area of } \\
\text { Bulk Fruits } \\
\text { (Decare) }\end{array}$ & $\begin{array}{l}\text { Produc-tion } \\
\text { (ton) }\end{array}$ & $\begin{array}{l}\text { Average } \\
\text { Yield per } \\
\text { Tree (kg) }\end{array}$ & $\begin{array}{c}\text { Number of } \\
\text { Fruitless } \\
\text { Trees }\end{array}$ & $\begin{array}{c}\text { Number of } \\
\text { Unfruitless } \\
\text { Trees }\end{array}$ & $\begin{array}{c}\text { Total } \\
\text { Number of } \\
\text { Fruit } \\
\text { Trees }\end{array}$ \\
\hline Pear & 244 & 405 & 18 & 22.065 & 7.605 & 29.670 \\
\hline Quince & 67 & 30 & 21 & 1.415 & 1.107 & 2.522 \\
\hline Almond & 4.130 & 1.898 & 12 & 159.947 & 93.461 & 253.408 \\
\hline Walnut & 1.166 & 481 & 14 & 33.543 & 6.407 & 39.950 \\
\hline Pistachio & 10.029 & 1.921 & 9 & 204.500 & 111.600 & 316.100 \\
\hline Apple & 1.012 & 795 & 22 & 35.850 & 5.092 & 40.492 \\
\hline Plum & 182 & 287 & 15 & 19.058 & 2.430 & 21.488 \\
\hline Mulberry & 34 & 495 & 17 & 28.490 & 3.270 & 31.760 \\
\hline Figs & 101 & 1.564 & 30 & 51.645 & 6.570 & 58.215 \\
\hline Apricot & 203 & 399 & 14 & 29.300 & 2.635 & 31.935 \\
\hline Cherry & 11.058 & 2.946 & 17 & 176.638 & 114.500 & 291.138 \\
\hline Nectarine & 60 & 58 & 15 & 3.850 & 80 & 3.930 \\
\hline Peach & 205 & 167 & 16 & 10.220 & 1.275 & 11.495 \\
\hline Pomegranate & 1.803 & 2.965 & 42 & 70.705 & 40.062 & 110.767 \\
\hline Persimmon & 5 & 6 & 9 & 650 & 40 & 690 \\
\hline Loquat & 0 & 6 & 7 & 850 & 52 & 902 \\
\hline Jerusalem & 0 & 13 & 8 & 1.660 & 12 & 1.672 \\
\hline Sour cherry & 40 & 72 & 10 & 6.925 & 669 & 7.594 \\
\hline Olive & 19.823 & 1.721 & 6 & 300.148 & 167.099 & 467.247 \\
\hline TOPLAM & 50.162 & 16.229 & 14 & 1.157 .459 & 563.966 & 1.721 .425 \\
\hline
\end{tabular}




\section{Artuklu district's fruit production potantial}

According to the year of 2016, Artuklu district has 2.467 tons of fruit potantial production, 243.008 of number of fruitful trees, 201.029 of number of unfruitful trees and 444.037 of total number of trees. Pear, almond, walnut, apple, plum, mulberry, pistachio, pomegranate, apricot olive and cherry are grown in Artuklu district. The highest fruit production was obtained from cherries with 671 tons. In this context, this district is suitable for the cultivation of many fruit species and varieties.

\section{Dargeçit district's fruit production potantial}

According to the year of Anonymus (2016), Dargeçit district has 424 tons of fruit potantial production, 32.562 of number of fruitful trees, 23.380 of number of unfruitful trees and 55.942 of total number of trees. Quince, almond, pistachio, walnut, apple, plum, mulberry, cherry, peach, pomegranate and apricot are grown in Dargeçit district. The highest fruit production was obtained from figs with 157 tons. In this context, this district is suitable for the cultivation of many fruit species and varieties

\section{Derik district's fruit production potantial}

According to the year of ANONYMUS (2016), Derik district has 2.191 tons of fruit potantial production, 233.720 of number of fruitful trees, 23.238 of number of unfruitful trees and 256.958 of total number of trees. Pear, almond, pistachio, walnut, mulberry, pomegranate, cherry, fig and apricot are grown in Derik district. The highest fruit production was obtained from olive with 647 tons. In this context, this district is suitable for the cultivation of many fruit species and varieties.

\section{Kızltepe district's fruit production potantial}

According to the year of ANONYMUS (2016), the districts where the most fruit production is done in the districts of Mardin are Kizıltepe with 3.424 tons. Kizlltepe district has 149.930 of number of fruitful trees, 91.770 of number of unfruitful trees and 241.700 of total number of trees. Pears, almonds, pistachios, walnuts, apples, plums, peaches, pomegranates, olives, figs and apricots are grown in Kizıltepe. The highest fruit production was obtained from pomegranate with 1.836 tons. In this context, this district is suitable for the cultivation of many fruit species and varieties.

\section{Mazıdağı District's Fruit Production Potantial}

According to the year of ANONYMUS (2016), with 207 tons.of production Mazidağ1 districts ranks the lowest in fruit production among the all districts of Mardin province. It has 18.430 of number of fruitful trees, out of 26.450 total number of trees. Pear, quince, almond, pistachio, apple, plum, mulberry, sour cherry, fig and apricot are grown in Mazıdağı district. The highest fruit production was obtained from walnut with 95 tons. In this context, this district is suitable for the cultivation of many fruit species and varieties. 


\section{Midyat District's Fruit Production}

According to the year of ANONYMUS (2016), Midyat is the last among the other districts of Mardin regarding number fruit species. Only seven fruit species, namely pears, pistachios, almond, walnuts, cherries, pomegranates and olives are grown in the Midyat district. Midyat district has 70.366 of number of fruitful trees out of 170.620 number of trees. The highest fruit production was obtained from almond with 508 tons. In this context, this district is suitable for the cultivation of some fruit species and varieties.

\section{Nusaybin District's Fruit Production Potantial}

According to the year of ANONYMUS (2016), the districts where the most fruit species is done in the districts of Mardin are Nusaybin with 20 numbers. Nusaybin district has 142.895 of number of fruitful trees, 22.615 of number of unfruitful trees and 165.510 of total number of trees. Pear, quince, pistachio, almond, walnut, apple, plum, mulberry, cherry, peach, nectarine, pomegranate, Persimmon, Loquat, cherry, wild apricot, olive, fig and apricot are grown in the Nusaybin district. The highest fruit production was obtained from almond with 508 tons. In this context, this district is suitable for the cultivation of some fruit species and varieties.

\section{Omerli district's fruit production}

According to the year of ANONYMUS (2016), Ömerli district has 2.903 tons of fruit potantial production, 106.490 of number of fruitful trees, 36.732 of number of unfruitful trees and 143.222 of total number of trees. Pear, almond, olive, pistachio, walnut, plum, mulberry, pomegranate, fig and apricot are grown in Ömerli district. The highest fruit production was obtained from olive with 960 tons. In this context, this district is suitable for the cultivation of many fruit species and varieties.

\section{Savur District's Fruit Production}

According to the year of ANONYMUS (2016), Savur district has 840 tons of fruit production, 83.565 of number of fruitful trees, 7.425 of number of unfruitful trees and 90.990 of total number of trees. Pear, quince, almond, pistachio, walnut, plum, mulberry, cherry, pomegranate, fig and apricot are processed in Savur district. The highest fruit production was obtained from apple with 322 tons. In this context, this district is suitable for the cultivation of many fruit species and varieties.

\section{Yeşilli District's Fruit Production}

According to the year of ANONYMUS (2016), Yeşilli district has 1.698 tons of fruit potantial production, 76.493 of number of fruitful trees, 49.503 of number of unfruitful trees and 125.996 of total number of trees. Pearl, quince, almond, walnut, apple, plum, mulberry, peach, pomegranate, persimmon, loquat, peach, pomegranate, wild apricot, olive, fig and apricot are grown in 
Yeşilli district. The highest fruit production was obtained from cherry with 1.051 tons. In this context, this district is suitable for the cultivation of many fruit species and varieties.

\section{Development Opportunities of Fruit Production Potantial of Mardin Province}

Fruit producers need to make regular cultural processes to reduce profit inefficiency. In order to reduce production costs, more contribution of the technical and scientific research is needed to increase fruit yield and quality. It is necessary to accelerate the development of new fruit species and varieties suitable for Mardin ecological conditions and planting systems Necessary and timely measures should be be taken done to prevent diseases and harms of orcharding. In order to achieve good quality production, fruit producers need to grow fruit with certified seedlings. Hazelnut producers have to make agricultural insurance for the loss of natural disasters. Fruit producers should act in cooperation with other institutions and organizations, In facilitating this, provincial governor may provide coordination of relevant institutions such as faculties of agriculture, vocational schools and institutes of the universities, under the coordination of provincial governors.

\section{References}

[1] Anonymus, (2016). Turkish Statistical Institute Retrieved June 1, 2017. https:// biruni. tuik.gov.tr/ bitkisel app/ bitkisel.zul. Erişim tarihi: 15.08.2017

[2] Anonymus, (2017a). https:// www.google. com.tr/search?rlz=1 C1CHWA_trTR616TR $617 \&$ biw $=1707 \& b i h=797 \&$ tbm=isch \&sa=1\&q=Mardin+Districts \&oq=Mardin+Districts \&gs_l= psyab.3...321008.363 920.0.364382. 14.12.2.0.0.0.182.140 4.2j10.12.0.......1. 1.64.psyab..0.8.723.. .0j0i24k1.YK5CYagD9 JA\#imgrc=flfxht7dNg1mAM: Erişim tarihi: 15.08.2017

[3] Anonymus, (2017b). Mardin climate and soil requirements http://www.cografya.gen.tr/tr/mardin/iklim.html. Retrieved May 10, 2017. (in Turkish). Erişim tarihi: 15.08 .2017

[4] Anonymus, (2017)c. Mardin Maps (MM). https://www. google. com.tr/ search?q= Mardin+Map\&rlz=1C1C HWA_trTR 616TR617 \&source=l nms\&tbm $=$ isch\&sa= X\&ved =0ahUKEwj- 2uX43NP VAhXIJZoKHRok BBYQ_AUICig B\&biw $=1707 \&$ bih=79 7\#imgrc=_cyvrQyrxsOZCM: Erişim tarihi: 15.08.2017 [1]

[5] Bostan, S.Z., Islam, A., (1999). Determination of interrelationships among important nut quality characteristics on Palaz and Sivri Hazelnut cultivars by Path Analysis. Tr. J. of Agriculture and Forestry, 23 (4): 371-375.

[2]

[6] Dizdaroğlu, T., (1985). Economic evaluation of peach, apricot and plum cultivation in İzmir's Menemen Village. (PhD Thesis). Ege University Science Institute, İzmir. 
[7] Gercekcioglu, R., Bilgener, S., \& Soylu, A., (2014). General orcharding (principles of fruit growing). NOBEL Academic Publishing, Improved 4th Edition, Istanbul, 498 p. (n Turkish).

[8] Özbek, S., (1975). Genel meyvecilik. Cukurova University agricultural faculty's publication (in Turkish).

[9] Simsek, M., Kara, A., (2016). Diyarbakir fruit growing potential an overview. International Diyarbakir Semposium 2-5 October 2016, Diyarbakır-Turkey (in press). 